\title{
Random coil chemical shifts for serine, threonine and tyrosine phosphorylation over a broad $\mathrm{pH}$ range
}

\author{
Ruth Hendus-Altenburger ${ }^{1}$ (D) Catarina B. Fernandes ${ }^{1}$ (D) Katrine Bugge $^{1}$ (D) Micha B. A. Kunze $^{1}$ (i) \\ Wouter Boomsma ${ }^{2}$. . Birthe B. Kragelund ${ }^{1}$ (D)
}

Received: 17 May 2019 / Accepted: 30 September 2019 / Published online: 9 October 2019

(c) The Author(s) 2019

\begin{abstract}
Phosphorylation is one of the main regulators of cellular signaling typically occurring in flexible parts of folded proteins and in intrinsically disordered regions. It can have distinct effects on the chemical environment as well as on the structural properties near the modification site. Secondary chemical shift analysis is the main NMR method for detection of transiently formed secondary structure in intrinsically disordered proteins (IDPs) and the reliability of the analysis depends on an appropriate choice of random coil model. Random coil chemical shifts and sequence correction factors were previously determined for an Ac-QQXQQ- $\mathrm{NH}_{2}$-peptide series with $\mathrm{X}$ being any of the 20 common amino acids. However, a matching dataset on the phosphorylated states has so far only been incompletely determined or determined only at a single $\mathrm{pH}$ value. Here we extend the database by the addition of the random coil chemical shifts of the phosphorylated states of serine, threonine and tyrosine measured over a range of $\mathrm{pH}$ values covering the $\mathrm{pKas}$ of the phosphates and at several temperatures (www.bio.ku.dk/sbinl $\mathrm{ab} / \mathrm{randomcoil)}$. The combined results allow for accurate random coil chemical shift determination of phosphorylated regions at any $\mathrm{pH}$ and temperature, minimizing systematic biases of the secondary chemical shifts. Comparison of chemical shifts using random coil sets with and without inclusion of the phosphoryl group, revealed under/over estimations of helicity of up to $33 \%$. The expanded set of random coil values will improve the reliability in detection and quantification of transient secondary structure in phosphorylation-modified IDPs.
\end{abstract}

Keywords Secondary structure $\cdot$ NMR $\cdot$ Phosphorylation $\cdot$ Post translational modification $\cdot$ Secondary chemical shift analysis $\cdot$ PTM $\cdot$ IDP $\cdot$ Random coil

Ruth Hendus-Altenburger and Catarina B. Fernandes have contributed equally to this work.

Electronic supplementary material The online version of this article (https://doi.org/10.1007/s10858-019-00283-z) contains supplementary material, which is available to authorized users.

Birthe B. Kragelund

bbk@bio.ku.dk

1 Structural Biology and NMR Laboratory, Department of Biology, University of Copenhagen, Ole Maaløes Vej 5, 2200 Copenhagen N, Denmark

2 Department of Computer Science, University of Copenhagen, Universitetsparken 1, 2100 Copenhagen $\varnothing$, Denmark

\section{Introduction}

Intrinsically disordered proteins (IDPs) are important components of the cellular signaling machinery (Wright and Dyson 2015) and they are abundant in most proteomes (Ward et al. 2004; Xue et al. 2012). They exist as an ensemble of interconverting dynamic conformations with varying amounts of transiently populated secondary structure. Phosphorylation mostly occurs in intrinsically disordered regions (Iakoucheva et al. 2004; Tyanova et al. 2013), and can have diverse effects on transiently populated secondary structures. In the literature, cases can be found where there is no effect on the secondary structure (Sibille et al. 2012), but also cases where varying degrees of (de)stabilization are seen (Miranda et al. 2004; Espinoza-Fonseca et al. 2008; Andrew et al. 2002; Bui and Gsponer 2014), depending in most instances on the immediate sequence context (HendusAltenburger et al. 2017). One of the most pronounced effects 
reported is the phosphorylation-induced global folding of the IDP 4EBP2, which is the major neural isoform of a family of three mammalian proteins that bind eIF4E and suppress cap-dependent translation initiation (Bah et al. 2015).

The most convenient and robust NMR method to identify secondary structures in proteins is based on the secondary chemical shift analysis (SCS, $\Delta \delta$ ). Chemical shifts $(\delta s, \mathrm{CSs})$ of the backbone nuclei and in particular those of $\mathrm{H}^{\alpha}, \mathrm{C}^{\alpha}$ and $\mathrm{C}^{\prime}$ correlate strongly with local backbone structure. By comparison to random coil CSs, one can derive secondary structure propensities and specifically identify the position, length and population of these in proteins. Yet, random coil CSs of individual residues vary depending on their neighboring residues (Wishart et al. 1995) as well as on experimental conditions (salt, $\mathrm{pH}$, temperature etc.) (Kjaergaard et al. 2011; Nielsen and Mulder 2018). This is critical, especially for IDPs as the transient nature of their secondary structure manifests in small SCSs, which means that small variations in the reference random coil libraries can lead to large biases. Currently, several datasets for reference CSs of commonly occurring amino acids exist that are based on either neighboring correction factors derived from peptide libraries (Kjaergaard et al. 2011; Kjaergaard and Poulsen 2011; Marsh et al. 2006), computational approaches (Camilloni et al. 2012), or curated CS data sets derived from disordered proteins (Nielsen and Mulder 2018; Tamiola et al. 2010). Posttranslational modifications (PTMs) affect the CSs, and the chemical effects of PTMs, like phosphorylation, on the random coil CSs are not yet included in any library. Previous studies have aimed to characterize the random coil CSs of phosphorylated amino acids using peptides (Bienkiewicz and Lumb 1999; Conibear et al. 2019). However, these studies were based on glycine peptides, and as glycines have unusual Ramachandran distributions, only some aspects of the neighbor-dependence are accounted for (Kjaergaard and Poulsen 2011). Furthermore, the effect of a PTM may extend further than to its immediate neighbors and previous work has not provided any correction factors for neighboring amino acid residues upon phosphorylation. Recent work on 18 differently modified amino acids measured the random coil CSs of phosphorylated serine, threonine and tyrosine in an Ac-GGXGG- $\mathrm{NH}_{2}$ context as well as reported neighboring effect, but only at $\mathrm{pH} 5.0$ (Conibear et al. 2019). This $\mathrm{pH}$ is not compatible with most studies on IDPs, which are typically conducted around physiological $\mathrm{pH}$ and at, or above, the $\mathrm{pI}$ of the phosphates.

At present, the most precise way to extract the inducible effect of either phosphorylation, other PTMs, or nonnatural amino acids is to use the chemically unfolded state as internal reference $\left(\delta_{\text {irc }}\right)$ to determine the SCSs (Modig et al. 2007). The use of the chemically unfolded state as internal reference does not require a reference library, as each protein can be used as its own internal reference. Thus, this approach has successfully been used in secondary structure analysis of a number of IDPs (Haxholm et al. 2015; Hendus-Altenburger et al. 2016; Kjaergaard et al. 2010), as well as to quantify the effect of multiple phosphorylations on secondary structure and the identification of a stabilizing phospho-motif in an IDP (Hendus-Altenburger et al. 2017). Yet, using the chemically unfolded state requires another round of assignment, homogeneous phosphorylations of all modified sites as well as identical sample conditions for all states, which is rather laborious. Moreover, the extent to which urea biases the CSs is not entirely clear (Elam et al. 2013; Whittington et al. 2005). Thus, peptide derived random coil shifts remain an efficient and accurate approach to examine the locally and globally induced structural changes of these modifications.

Here, we expand the previous dataset of random coil CSs and sequence correction factors recorded on the AcQQXQQ- $\mathrm{NH}_{2}$ peptide series (Kjaergaard and Poulsen 2011) by including the phosphorylated states of serine, threonine and tyrosine (referred to as pSer, pThr and pTyr). The results have been implemented in an online predictor at www.bio. ku.dk/sbinlab/randomcoil. We have explored the effects at various experimental conditions that are likely to be relevant for phosphorylations in IDPs, specifically the temperatureand $\mathrm{pH}$ dependence of the phosphorylated state random coil CSs covering the pKas of the phosphates. Although this dataset was determined with IDPs and the effect of their phosphorylation in mind, it should be equally applicable for folded proteins.

\section{Materials and methods}

Peptides with the sequence Ac-QQXQQ- $\mathrm{NH}_{2}$ were purchased from KJ Ross-Petersen ApS (Denmark) and from Schafer N (Denmark), where X was either serine, threonine or tyrosine without or with (pSer, pThr or pTyr) phosphorylation ( $\geq 95 \%$ purity by reversed phase HPLC, identities confirmed by mass spectrometry).

Peptide samples for circular dichroism (CD) analyses were prepared in $20 \mathrm{mM}$ sodium phosphate buffer to a final approximate concentration of $250 \mu \mathrm{M}$ (pH 6.5, with or without $150 \mathrm{mM} \mathrm{NaF}$ ). Far-UV CD spectra were recorded from 260 to $190 \mathrm{~nm}$ on a Jasco 815 spectropolarimeter in $0.1 \mathrm{~cm}$ quartz cuvettes, and with Peltier controlled temperatures set to $5{ }^{\circ} \mathrm{C}$ or $35^{\circ} \mathrm{C}$. Each spectrum was recorded at a scan rate of $10 \mathrm{~nm} / \mathrm{min}$, band width $1 \mathrm{~nm}$, and a response time of $2 \mathrm{~s}$ and averaged over 10 scans. To enable comparison at equal concentrations, especially as the serine, pSer, threonine, and pThr peptides lack absorbance at $280 \mathrm{~nm}$, the signals were normalized using the HT level. Background spectra were recorded identically and subtracted. The final spectra were smoothed using the FFT function in the Jasco software. 
NMR samples were prepared by dissolving 2-3 mg of peptide in $500 \mu \mathrm{L} 20 \mathrm{mM}$ sodium phosphate buffer $\mathrm{pH} 6.5$ containing 5\% (v/v) $\mathrm{D}_{2} \mathrm{O}, 3 \mathrm{mM} \mathrm{NaN}_{3}$, and $1 \mathrm{mM} \mathrm{DSS}$. $\mathrm{pH}$ was adjusted to 6.5 by the addition of small quantities of $\mathrm{HCl}$ or $\mathrm{NaOH}$ or in urea as described (Hendus-Altenburger et al. 2017). All NMR spectra were acquired on either a Varian Unity $800 \mathrm{MHz}$ spectrometer equipped with a room temperature probe or a $600 \mathrm{MHz}$ Bruker Avance III HD spectrometer with a cryo-probe. CSs were referenced to internal DSS as previously described (Wishart et al. 1995). For each sample the following spectra were acquired at natural isotope abundance: $1 \mathrm{D}{ }^{1} \mathrm{H}$ (zgesgp), ${ }^{1} \mathrm{H}-{ }^{15} \mathrm{~N}$ HSQC (hsqcetfpf3gpsi), ${ }^{1} \mathrm{H}-{ }^{13} \mathrm{C}$ HSQC (hsqcetgpsisp2.2), 2D TOCSY (Piotto et al. 1992) (mlevgpph19, mixing time $80 \mathrm{~ms}$ ), 2D ROESY (roesygpph19.2, mixing time $300 \mathrm{~ms}$ ) and ${ }^{1} \mathrm{H}^{\alpha}{ }^{13} \mathrm{CO}$ HSQC (HACO_hsqcetgpsi) (Kjaergaard et al. 2011). The ${ }^{1} \mathrm{H}^{\alpha}{ }^{13} \mathrm{CO}$ HSQC experiment correlates the $\mathrm{H}^{\alpha}$ protons with the carbonyl resonances of the same and the preceding residue. For all peptides, data were recorded at $5{ }^{\circ} \mathrm{C}, 15^{\circ} \mathrm{C}, 25^{\circ} \mathrm{C}$, and $35^{\circ} \mathrm{C}$. NMR data were processed using NMRPipe (Delaglio et al. 1995) and analyzed using CCPNMR Analysis (Vranken et al. 2005). The ${ }^{3} \mathrm{~J}_{\mathrm{HNHA}}$ coupling constants were measured by the peak splitting of the $\mathrm{H}^{\mathrm{N}}$-signals in the 1D ${ }^{1} \mathrm{H}$ NMR spectra.

Temperature coefficients were determined at both $\mathrm{pH} 5.0$ and $\mathrm{pH} 6.5$ by least squares fitting of the chemical shift $\delta$ to a linear function of temperature T, Eq. (1), where ' $a$ ' is the temperature coefficient:

$\delta_{\mathrm{rc}}(\mathrm{T})=\delta_{\mathrm{rc}}\left(25^{\circ} \mathrm{C}\right)+\mathrm{a}(\mathrm{T}-25)$

Under the assumption that the CS at the center residue of the peptide can be expressed as a linear function of contributions from its neighboring residues, the sequence corrected random coil CSs can be calculated at any temperature using Eq. (2):

$\delta_{\mathrm{rc}}(\mathrm{T})=\delta_{\mathrm{rc}}\left(25^{\circ} \mathrm{C}\right)+\mathrm{a}(\mathrm{T}-25)+\mathrm{A}+\mathrm{B}+\mathrm{C}+\mathrm{D}$

where $\mathrm{A}, \mathrm{B}, \mathrm{C}$ and $\mathrm{D}$ are the correction terms of the subsequent/previous residues. ' $\mathrm{A}$ ' is the sequence correction factor obtained by subtracting the CSs of Q1 of the Ac-QQQQQ$\mathrm{NH}_{2}$ peptide from that of the Ac-QQXQQ- $\mathrm{NH}_{2}$ peptides. ' $\mathrm{B}$ ', ' $\mathrm{C}$ ' and ' $\mathrm{D}$ ' correspond to the differences for Q2, Q4, and Q5, respectively.

For the phosphopeptides, NMR titration series from $\mathrm{pH}$ 8.0 to 4.0 in steps of $\sim 0.5$ were recorded. Samples were prepared by dissolving $2-3 \mathrm{mg}$ of peptide in $500 \mu \mathrm{L} 20 \mathrm{mM}$ sodium phosphate buffer, $\mathrm{pH} 8.0$, containing $5 \%(\mathrm{v} / \mathrm{v}) \mathrm{D}_{2} \mathrm{O}$, $3 \mathrm{mM} \mathrm{NaN}_{3}$, and $1 \mathrm{mM} \mathrm{DSS}$, and adjusting the $\mathrm{pH}$ stepwise by addition of $\mathrm{HCl}$. For these experiments, the NMR spectra were recorded at $5{ }^{\circ} \mathrm{C}$ to minimize exchange of the amide protons with the solvent. The changes in CSs were treated as a linear combination of the CS of a fully protonated and a fully deprotonated species and thus follow Eq. (3):
$\delta=\delta_{A} \times \frac{K_{A}}{10^{-p H}+K_{A}}+\delta_{H A} \times\left(1-\frac{K_{A}}{10^{-p H}+K_{A}}\right)$

$\delta_{\mathrm{HA}}$ and $\delta_{\mathrm{A}}$ represent the random coil CSs of the fully protonated and fully deprotonated species, respectively. $K_{a}$ is the acid dissociation constant of the side chain. The CSs were fitted to Eq. (3), where $K_{a}$ was treated as a global fitting parameter. The protonation/deprotonation of the $\mathrm{N}$ - and C-termini could be neglected due to N-terminal acetylation and C-terminal amidation.

As is evident from the expressions above, calculation of the random coil shifts is computationally efficient. The parameters are stored in simple lookup tables in a Javascript program, extending the previous implementation (Kjaergaard et al. 2011) with three additional residue types. To provide support for calculating neighbor-dependent correction factors at all $\mathrm{pH}$ values, we linearly interpolated between the recorded values in our range (corresponding to the lines connecting the observations in Fig. 2). The script supports calculation for entire sequences at once. Since there is no established single-letter notation for the phosphorylated amino acids, we allow mixing of single-letter and multiletter amino code specification by surrounding the latter by parentheses. For instance, the string "A(Ala)(pSer)" is interpreted as two alanines followed by a phosphorylated serine. The phosphorylated amino acid can be specified using several common conventions, i.e. either pS, pT, pY, pSer, pThr, pTyr, or Sep, Tpo, Ptr. The on-line predictor can be found at: www.bio.ku.dk/sbinlab/randomcoil.

To test the performance of the new predictor, the chemical shifts of six phosphorylated proteins were extracted from the BMRB database. These include the sodium proton exchanger 1 (NHE1) (BMRB 26755 and 27812) (HendusAltenburger et al. 2017; Hendus-Altenburger et al. 2016), the kinase inducible transactivation domain (KID) (BMRB 6784 and 6788) (Radhakrishnan et al. 1998), the transcriptional regulator protein Ash1 (BMRB 26719 and 26720) (Martin et al. 2016), the disordered cytosolic domain CD79a of the B cell receptor (BMRB 19644 and 19648) (Rosenlow et al. 2014), the regulatory region of the cystic fibrosis transmembrane conductance regulator (CFTR) (BMRB 15336 and 15340) (Baker et al. 2007) and the transcriptional activation domain of the transcription factor Elk-1 (BMRB 26762 and 26786) (Mylona et al. 2016).

\section{Results and discussion}

The change in NMR CSs upon PTMs of proteins is due to the changed local chemical environment but can in addition be caused by accompanying structural rearrangements induced by the PTM. While the chemical effect is 
Fig. 1 NMR spectra of the Ac-QQXQQ- $\mathrm{NH}_{2}$ phosphopeptides. The CSs were assigned from combining a 2D TOCSY (black) and ROESY (red), b ${ }^{1} \mathrm{H}-{ }^{15} \mathrm{~N}$ HSQC, ${ }^{1} \mathrm{H}-{ }^{13} \mathrm{C}$ HSQC spectra. d ROE patterns for Ac-QQpXQQ- $\mathrm{NH}_{2}$ phosphopeptides (pH $6.5,5^{\circ} \mathrm{C}$ ). The intensities of the ROEs are indicated by the height of the black bars
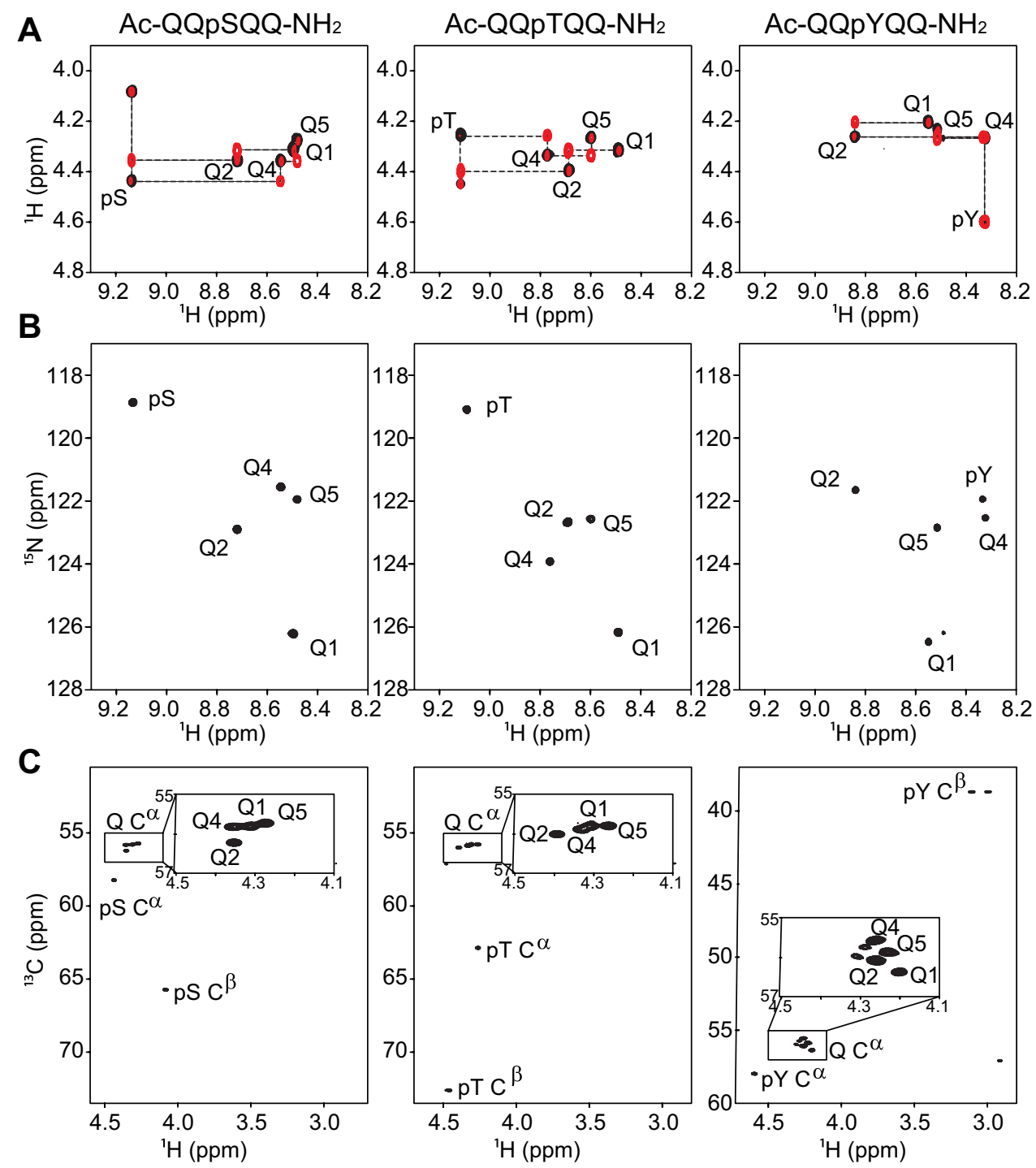

D
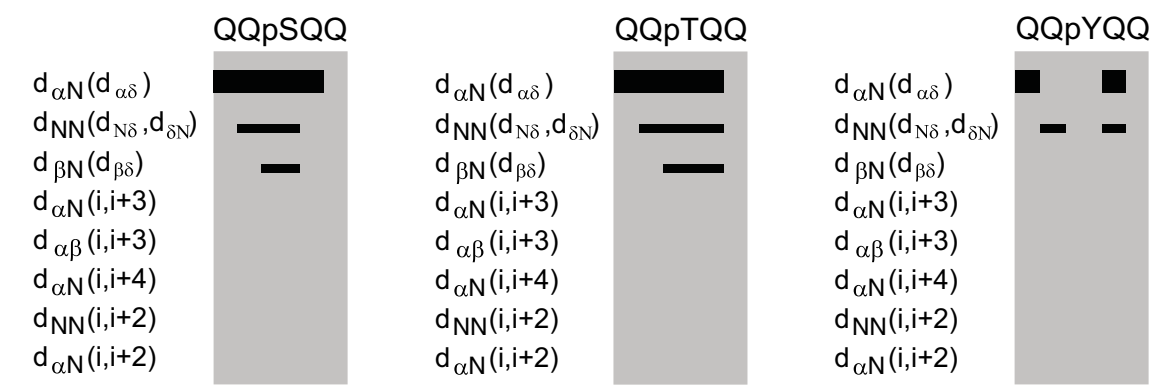

not expected to reach further than 2-3 residues on either side of the modified residue in the random coil state, structural rearrangements or changes in the conformational ensembles of IDPs can have long-range effects (HendusAltenburger et al. 2017). In order to allow for secondary structure analysis in the presence of phosphorylation we extended the previously published Ac-QQXQQ- $\mathrm{NH}_{2}$ peptide random coil CS database to include those for phosphorylated serine (pSer), threonine (pThr) and tyrosine (pTyr) residues. Furthermore, the random coil CS were extracted for various temperatures and at $\mathrm{pH}$ values ranging from $\mathrm{pH}$ 4.0 to 8.0 to cover the pKas of the phosphates.

Assignments and CSs for serine, threonine and tyrosine in the Ac-QQXQQ- $\mathrm{NH}_{2}$ context were readily transferred from the previous study (Kjaergaard and Poulsen 2011) and the CSs of their phosphorylated states were assigned by a combination of TOCSY and ROESY spectra (Fig. 1a). The random coil CSs of $\mathrm{C}^{\alpha}, \mathrm{C}^{\beta}, \mathrm{C}^{\prime}, \mathrm{N}, \mathrm{H}^{\mathrm{N}}$ and $\mathrm{H}^{\alpha}$ were 
Table 1 Random coil CSs at $\mathrm{pH}$ 6.5 and $5^{\circ} \mathrm{C}$

\begin{tabular}{lllllll}
\hline & \multicolumn{6}{l}{$\delta_{\mathrm{RC}}(\mathrm{ppm})$} \\
\cline { 2 - 6 } & $\mathrm{C}^{\alpha}$ & $\mathrm{C}^{\beta}$ & $\mathrm{C}^{\prime}$ & $\mathrm{N}$ & $\mathrm{H}^{\mathrm{N}}$ & $\mathrm{H}^{\alpha}$ \\
\hline Ser & 58.60 & 63.71 & 174.80 & 117.63 & 8.59 & 4.44 \\
Thr & 62.15 & 69.88 & 174.65 & 116.38 & 8.41 & 4.34 \\
Tyr & 57.97 & 38.65 & 175.77 & 121.79 & 8.40 & 4.59 \\
pSer & 58.24 & 65.73 & 174.77 & 118.87 & 9.13 & 4.44 \\
pThr & 62.99 & 72.45 & 174.57 & 119.10 & 9.09 & 4.25 \\
pTyr & 57.99 & 38.70 & 175.79 & 121.94 & 8.34 & 4.60 \\
\hline
\end{tabular}

determined for each phosphopeptide at different temperatures $\left(5-35{ }^{\circ} \mathrm{C}\right)$ and in the physiological $\mathrm{pH}$ range from $\mathrm{pH}$ 4.0-8.0, by recording the following spectra: ${ }^{1} \mathrm{H}-{ }^{15} \mathrm{~N}$ HSQC, ${ }^{1} \mathrm{H}-{ }^{13} \mathrm{C}$ HSQC, 2D TOCSY, and ${ }^{1} \mathrm{H}^{\alpha}-{ }^{13} \mathrm{CO}$ HSQC. The CSs of the phosphorylated residues of the peptides at $\mathrm{pH} 6.5$ and $5{ }^{\circ} \mathrm{C}$ are tabulated in Table 1 .

The amide peaks were well resolved in the ${ }^{1} \mathrm{H}-{ }^{15} \mathrm{~N}$ HSQC spectra of all three phosphorylated peptides (Fig. 1b) and their CSs were readily assigned as indicated in the ${ }^{1} \mathrm{H}-{ }^{13} \mathrm{C}-\mathrm{HSQC}$ spectra (Fig. 1c). For pSer and pThr, strong downfield shifts of the backbone amides were observed compared to the unphosphorylated counterparts. In contrast, tyrosine phosphorylation did not induce a similar large downfield shift of the modified residue, likely due to the more distal position of the modified hydroxyl group in the side chain relative to the backbone amide (Bienkiewicz and Lumb 1999; Theillet et al. 2012) (Table 1). These are important observations, as in several cases (transient) hydrogen bonds between the phospho-group and the amide of the same or neighboring residues were observed upon phosphorylation (Du et al. 2005; Ramelot and Nicholson 2001; Kang et al. 2010). We note that Q2 of the pTyr peptide showed a strong down-field shift suggesting this residue to be more affected than the tyrosine amide itself, which indicates that the CS of the residue prior to a pTyr can be used diagnostically to identify phosphorylation of tyrosine residues by NMR.

Within error, the random coil shifts for pTyr as well as the shift of its neighboring glutamines were identical to those of the non-phosphorylated peptides, testifying to the random coil nature of the phosphorylated peptide. However, for pSer and pThr, the shifts deviated from those of the nonphosphorylated peptides and together with the downfield shift of the amide, this could indicate structure formation. Thus, to address if the phosphates in these peptides induce structure, we recorded far-UV CD spectra of the phosphorylated as well as non-phosphorylated peptides at different temperatures $\left(5^{\circ} \mathrm{C}\right.$ and $\left.35^{\circ} \mathrm{C}\right)$ and in the absence and presence of $150 \mathrm{mM} \mathrm{NaF}$ (SI Fig. S1). The peptides were all in a random coil state as judged by the negative ellipticity at $198 \mathrm{~nm}$ and the slight positive signal at $215 \mathrm{~nm}$. Besides a more pronounced negative ellipticity at $198 \mathrm{~nm}$ for the phosphorylated peptides, indicating slightly more extended structure, phosphorylation did not change the $\mathrm{CD}$ spectra, neither did the presence of $150 \mathrm{mM} \mathrm{NaF}$. At $35^{\circ} \mathrm{C}$, we observed a minor change in the $\mathrm{CD}$ profile towards a slight redistribution away from polyproline II structure, as observed previously for IDPs (Kjaergaard et al. 2010). Finally, we compared the ${ }^{1} \mathrm{H},{ }^{13} \mathrm{C}$-HSQC spectra recorded on Ac-QQpSQQ-NH ${ }_{2}$ and Ac-QQpTQQ- $\mathrm{NH}_{2}$ in the absence and presence of $150 \mathrm{mM} \mathrm{NaCl}$ (SI Fig. S2), which showed the $\mathrm{C}^{\alpha}, \mathrm{C}^{\beta}$, and $\mathrm{H}^{\alpha} \mathrm{CSs}$ to be similar. Thus, the presence of salt at physiological concentrations does not change the conformational ensemble of these peptides.

An overlay of the ${ }^{15} \mathrm{~N}-\mathrm{HSQC}$ spectra of the phosphorylated and non-phosphorylated peptides showed that the glutamine side chain resonances did not readily superimpose (SI Fig. S3), indicating that the phosphates changed the chemical environment of these and/or induced structure. Therefore, to further substantiate the random coil nature of the phosphorylated peptides, we analyzed ROESY spectra for connectivity beyond those of sequential origin. All phosphorylated peptides showed stronger $\mathrm{H}^{\alpha}-\mathrm{H}^{\mathrm{N}}(\mathrm{i}, \mathrm{i}+1)$ inter-residue cross-peaks, and weaker $\mathrm{H}^{\mathrm{N}}-\mathrm{H}^{\mathrm{N}}(\mathrm{i}, \mathrm{i}+1)$ cross peaks (Fig. 1d), showing that the phosphorylated peptides are indeed random coil and have no secondary structure related interactions (Bienkiewicz and Lumb 1999; Dyson and Wright 1991). We repeated the ROESY spectra in the presence of $150 \mathrm{mM} \mathrm{NaCl}$ and $8 \mathrm{M}$ urea. These changes did not alter the peak intensity patterns and thus the ensembles remained similar (SI Fig. S4).

The temperature dependence of the backbone CSs was next determined from a series of NMR spectra recorded at $5{ }^{\circ} \mathrm{C}, 15{ }^{\circ} \mathrm{C}, 25{ }^{\circ} \mathrm{C}$ and $35{ }^{\circ} \mathrm{C}$. The CSs changed linearly with temperature (Fig. 2) and the CSs and temperature coefficients for each residue type and nuclei were readily extracted (Table 1). Temperature coefficients for the amide protons can serve as indicators for hydrogen bond formation (Cierpicki and Otlewski 2001), although this has been debated (Tholey et al. 1999; Kim et al. 2011; Rani and Mallajosyula 2017). None of the three phosphopeptides revealed amide temperature coefficients larger (more positive) than $-4.6 \mathrm{ppb} / \mathrm{K}$ neither at $\mathrm{pH} 6.5$ or at $\mathrm{pH} 5.0$ (Fig. 2b), which suggests that phosphorylation may not be enough to form a 
A
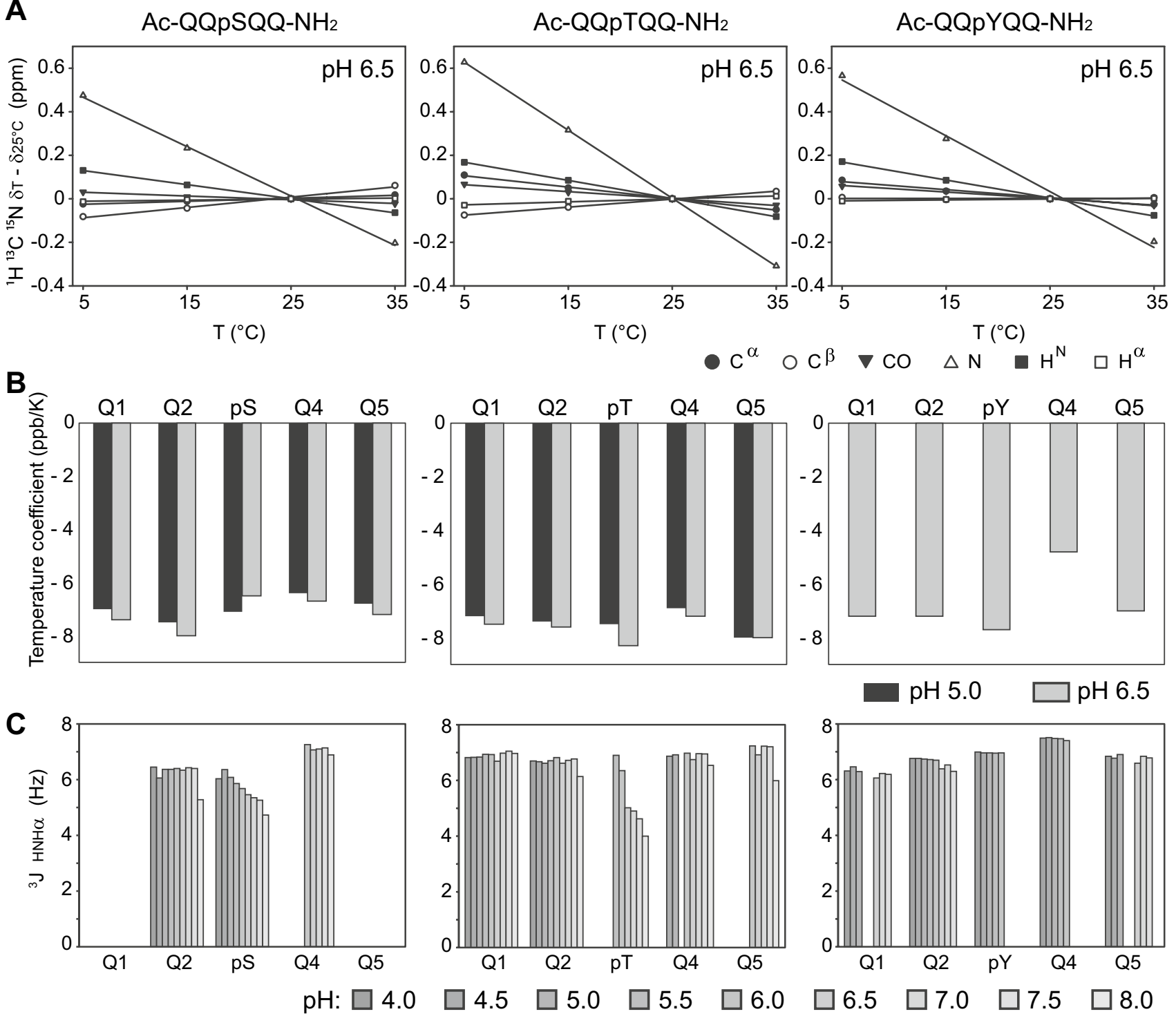

$\mathrm{pH} 5.0$

$\mathrm{pH} 6.5$
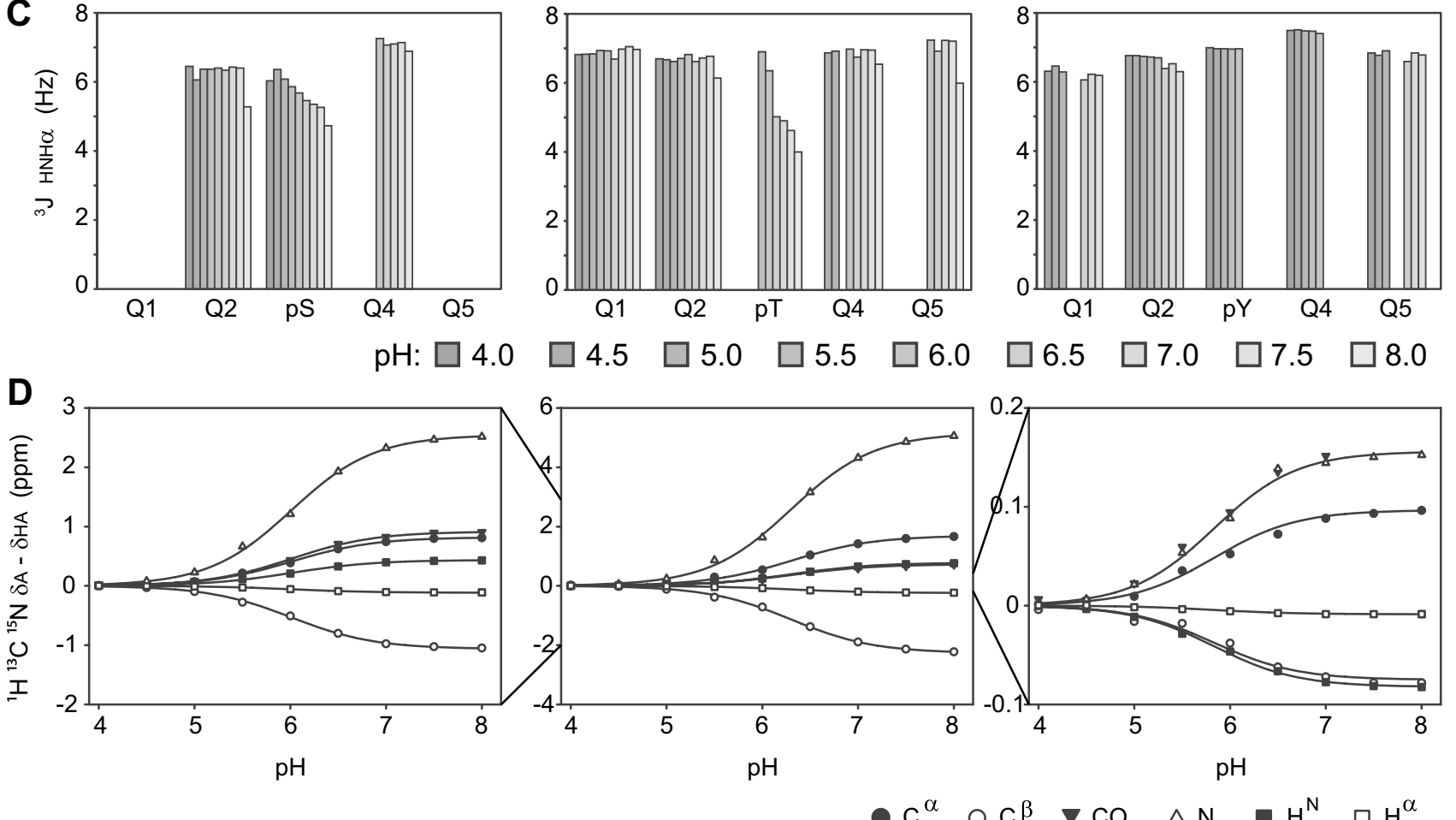

Fig. 2 Temperature and $\mathrm{pH}$ dependence of the random coil chemical shifts of the Ac-QQXQQ- $\mathrm{NH}_{2}$ phosphopeptides. a Temperature dependence of the chemical shifts of pSer, pThr and pTyr recorded at $\mathrm{pH}$ 6.5. Random coil chemical shifts assigned at $25^{\circ} \mathrm{C}$ were subtracted from the shifts recorded at the other temperatures to allow the different nuclei to be presented together. Lines represent the best linear fit to the change in chemical shifts, from which the temperature coefficients were extracted. b Temperature coefficients of the amide protons of the phosphopeptides at $\mathrm{pH} 6.5$ (pSer, pThr, pTyr) and $\mathrm{pH}$ 5.0 (pSer, pThr). ${ }^{3} \mathrm{~J}_{\mathrm{HNH} \alpha}$ coupling constants as a function of $\mathrm{pH}$ for pSer, pThr and pTyr. Missing bars are either due to decoupling or severe peak overlap. $\mathbf{d}$ The $\mathrm{pH}$ dependence of the chemical shifts of pSer, pThr, and pTyr determined in a titration series from $\mathrm{pH} 4.0$ to 8.0 at $5{ }^{\circ} \mathrm{C}$ 
Table 2 Random coil CSs of the fully protonated and fully deprotonated phosphorylated residues at $5{ }^{\circ} \mathrm{C}$

\begin{tabular}{|c|c|c|c|c|c|c|c|c|}
\hline & $\begin{array}{l}\mathrm{Ka} \\
\mathrm{pKa}\end{array}$ & & $C^{\alpha}$ & $\mathrm{C}^{\beta}$ & $\mathrm{C}^{\prime}$ & $\mathrm{N}$ & $\mathrm{H}^{\mathrm{N}}$ & $\mathrm{H}^{\alpha}$ \\
\hline \multirow[t]{3}{*}{ pSer } & \multirow{3}{*}{$\begin{array}{l}9.76 \times 10^{-7} \\
6.01\end{array}$} & $\delta_{\mathrm{HA}}$ & 57.61 & 66.53 & 174.06 & 116.94 & 8.81 & 4.52 \\
\hline & & $\delta_{\mathrm{A}}$ & 58.43 & 65.46 & 174.98 & 119.49 & 9.24 & 4.41 \\
\hline & & $\delta_{\mathrm{A}}-\delta_{\mathrm{HA}}$ & 0.82 & -1.07 & 0.92 & 2.55 & 0.43 & -0.11 \\
\hline \multirow[t]{3}{*}{ pThr } & \multirow{3}{*}{$\begin{array}{l}5.00 \times 10^{-7} \\
6.30\end{array}$} & $\delta_{\mathrm{HA}}$ & 61.83 & 73.99 & 174.06 & 115.94 & 8.62 & 4.41 \\
\hline & & $\delta_{\mathrm{A}}$ & 63.52 & 71.72 & 174.79 & 121.10 & 9.40 & 4.17 \\
\hline & & $\delta_{\mathrm{A}}-\delta_{\mathrm{HA}}$ & 1.69 & -2.27 & 0.73 & 5.16 & 0.79 & -0.24 \\
\hline \multirow[t]{3}{*}{ pTyr } & \multirow{3}{*}{$\begin{array}{l}1.47 \times 10^{-6} \\
5.83\end{array}$} & $\delta_{\mathrm{HA}}$ & 57.91 & 38.76 & 175.61 & 121.80 & 8.40 & 4.60 \\
\hline & & $\delta_{\mathrm{A}}$ & 58.00 & 38.69 & 175.79 & 121.95 & 8.32 & 4.59 \\
\hline & & $\delta_{\mathrm{A}}-\delta_{\mathrm{HA}}$ & 0.09 & -0.07 & 0.18 & 0.15 & -0.08 & -0.01 \\
\hline
\end{tabular}

persistent hydrogen bond with the backbone amide. However, measurements of the ${ }^{3} \mathrm{~J}_{\mathrm{HNHA}}$ coupling constants over a pH range from 4.0 to 8.0 showed that those of the phosphorylated serine and threonine, but not those of the tyrosine or the glutamines, were $\mathrm{pH}$ dependent. At low $\mathrm{pH}$, the ${ }^{3} \mathrm{~J}_{\mathrm{HNHA}}$ coupling constants had random coil values (Shen et al. 2018), but decreased and reached 4.7 Hz (pSer) and $4.0 \mathrm{~Hz}$ (pThr), respectively, at pH 8.0 (Fig. 2c). This either suggests that there is steric exclusion from the presence of the phosphoryl groups or that a (transient) hydrogen bond is formed in the deprotonated state. The latter conclusion is in line with the literature (Du et al. 2005; Tholey et al. 1999; Kim et al. 2011; Mandell et al. 2007; Lee et al. 2008) and suggest that a (transient) hydrogen bond may be part of the high $\mathrm{pH}$-random coil state of pSer and pThr. The remaining context, constituted by the four glutamines, were random coil in the entire temperature- and $\mathrm{pH}$ range analyzed and in the presence of salt. Thus, we conclude that these peptides are suitable representations of the phosphorylated random coil state.

The random coil CSs of the backbone change with the protonation state of the side chains and with the potential hydrogen bond formation at high $\mathrm{pH}$, so to allow the random coil CSs to be used in a range of $\mathrm{pH}$ values, $\mathrm{pH}$ titrations were carried out for peptides with pSer, pThr and pTyr (Fig. 2d). The CSs at different $\mathrm{pH}$ values were then fitted to Eq. (3), which describes the observed CSs as a linear combination of the CSs for the fully protonated and the fully deprotonated states, respectively, as a function of $\mathrm{pH}$ (Table 2). From these fits, we obtained $\mathrm{pKa}$ values for $\mathrm{pSer}$, pThr and pTyr, of 6.01, 6.30 and 5.83, respectively; similar, but not identical, to the previously determined values for Ac-GGXGG-NH ${ }_{2}$ peptides (pKa 5.96, 6.30, 5.96) (Bienkiewicz and Lumb 1999) and to those in a GGXA context (pKa 6.1, 6.1, 5.9) (Hoffmann et al. 1994). The largest differences in CSs between the protonated and deprotonated state were those observed for the amide nitrogen, and strongest for $\mathrm{pThr}(\Delta \delta \mathrm{N}=5.16)$, followed by $\mathrm{pSer}(\Delta \delta \mathrm{N}=2.55)$, and only small differences were observed for pTyr $(\Delta \delta \mathrm{N}=0.15)$
(Fig. 2d; Table 2). Importantly, the amplitude of the change in CS occurring by altering the protonation state is in the same range - or even larger - as for transient structure formation in IDPs. Thus, these effects may falsely be interpreted as such, unless the random coil CSs used in the calculations are matched to the $\mathrm{pH}$ of the NMR sample. However, the $\mathrm{pKa}$ value of individual phosphorylation sites in the protein context will depend on several other factors, including the presence of charges or polar residues in the neighboring sequence, additional phosphorylation sites (Tamiola et al. 2018), as well as local or, in the case of a folded protein, the global protein conformation (Buckingham 1960; Kukic et al. 2013; Wishart 2011; Tomlinson et al. 2010). In these cases, care should be taken in interpreting effects of phosphorylation, and a $\mathrm{pKa}$ determination of the different sites in urea, which may also provide the intrinsic random coils shifts, can be a solution.

\section{Sequence correction}

The effect of phosphorylation on the CSs may extend beyond the nearest neighbor residue and sequence correction factors were therefore extracted for residue $\mathrm{X}$ by subtracting the CSs of the Ac-QQQQQ- $\mathrm{NH}_{2}$ peptide from those of the AcQQXQQ-NH $\mathrm{N}_{2}$ peptide (Table 3) (Schwarzinger et al. 2001). Generally, the sequence correction factors for carbon nuclei are larger for residues further away on the $\mathrm{N}$-terminal side, whereas for the amide, they are larger on the C-terminal side. Also, the sign of the effect is opposite for pTyr compared to pThr and pSer, likely due to ring current effects. The largest effects are in the order of $0.35-0.6 \mathrm{ppm}$, which means that if not accounted for, this can lead to an over/ underestimation of the helical content of the region by up to $20 \%$ [assuming $100 \%$ helicity will result in SCS of $2.8 \mathrm{ppm}$ (Fedyukina et al. 2010)], a number that is close to the typical population of helicity in IDPs (Hendus-Altenburger et al. 2017; Forman-Kay and Mittag 2013). Importantly, this also suggests that we may miss the identification of direct 
Table 3 Glutamine derived sequence correction factors at $\mathrm{pH} 6.5,5{ }^{\circ} \mathrm{C}$

\begin{tabular}{|c|c|c|c|c|c|c|c|c|c|c|c|c|}
\hline & \multicolumn{4}{|l|}{$\mathrm{C}^{\alpha}$} & \multicolumn{4}{|l|}{$\mathrm{C}^{\beta}$} & \multicolumn{4}{|l|}{$\mathrm{C}^{\prime}$} \\
\hline & A & B & $\mathrm{C}$ & D & A & B & $\mathrm{C}$ & D & A & B & $\mathrm{C}$ & $\mathrm{D}$ \\
\hline pSer & -0.30 & 0.18 & -0.16 & -0.01 & 0.01 & 0.08 & -0.18 & -0.06 & -0.14 & 0.25 & 0.00 & 0.12 \\
\hline pThr & -0.30 & -0.04 & -0.10 & 0.06 & 0.08 & 0.21 & 0.00 & -0.03 & -0.37 & 0.07 & -0.13 & 0.10 \\
\hline \multirow[t]{3}{*}{ pTyr } & 0.26 & 0.04 & -0.40 & 0.13 & -0.15 & -0.51 & 0.08 & -0.02 & -0.03 & -0.25 & -0.61 & 0.05 \\
\hline & \multicolumn{4}{|l|}{$\mathrm{N}$} & \multicolumn{4}{|l|}{$\mathrm{H}^{\mathrm{N}}$} & \multicolumn{4}{|l|}{$\mathrm{H}^{\alpha}$} \\
\hline & A & B & $\mathrm{C}$ & $\mathrm{D}$ & A & B & $\mathrm{C}$ & D & A & B & $\mathrm{C}$ & $\mathrm{D}$ \\
\hline pSer & -0.02 & 0.72 & -0.76 & -0.82 & -0.01 & -0.01 & -0.12 & -0.17 & 0.03 & 0.03 & 0.03 & -0.03 \\
\hline pThr & -0.05 & 0.48 & 1.62 & -0.19 & -0.02 & -0.04 & 0.09 & -0.06 & 0.03 & 0.07 & 0.01 & -0.04 \\
\hline pTyr & 0.25 & -0.53 & 0.23 & 0.08 & 0.04 & 0.11 & -0.34 & -0.14 & -0.08 & -0.06 & -0.05 & -0.07 \\
\hline
\end{tabular}

' $\mathrm{A}$ ' is the sequence correction factor obtained by subtracting the CS of Q1 of the Ac-QQQQQ- $\mathrm{NH}_{2}$ peptide from that of the Ac-QQXQQ-NH 2 peptides. 'B', 'C' and 'D' correspond to the differences for Q2, Q4, and Q5, respectively

Table 4 CSs of phosphorylated proteins available in the BMRB and used in this study

\begin{tabular}{|c|c|c|}
\hline Protein & Phosphorylation sites (kinase) & BMRB \\
\hline $\mathrm{Na}^{+} / \mathrm{H}^{+}$exchanger 1 (NHE1), disordered distal tail & $\begin{array}{l}\text { Ser693, Ser723, Ser726, Ser771, Thr779, Ser785 } \\
\text { (MAP kinase ERK2) }\end{array}$ & $\begin{array}{l}26755 \\
27812 \text { (Hendus-Altenburger et al. } \\
\text { 2017; Hendus-Altenburger et al. } \\
\text { 2016) }\end{array}$ \\
\hline $\begin{array}{l}\text { Kinase inducible transactivation (KID) domain of the } \\
\text { transcription factor CREB }\end{array}$ & Ser133 (Protein kinase A, PKA) & $\begin{array}{l}6784 \\
6788 \text { (Radhakrishnan et al. 1998) }\end{array}$ \\
\hline $\begin{array}{l}\text { Regulatory region of the cystic fibrosis transmem- } \\
\text { brane conductance regulator (CFTR) }\end{array}$ & $\begin{array}{l}\text { Ser660, Ser700, Ser712, Ser737, Ser753, Ser768, } \\
\text { Ser795, Ser813 (Protein kinase A, PKA) }\end{array}$ & $\begin{array}{l}15336 \\
15340 \text { (Baker et al. 2007) }\end{array}$ \\
\hline Transcriptional regulator protein Ash1 & $\begin{array}{l}\text { Ser424, Ser426, Thr429, Ser442, Thr450, Ser452, } \\
\text { Ser455, Ser465, Ser469, Ser490 (cyclin A/Cdk2) }\end{array}$ & $\begin{array}{l}26719 \\
26720 \text { (Martin et al. 2016) }\end{array}$ \\
\hline Activation domain of the transcription factor Elk-1 & $\begin{array}{l}\text { Thr337, Thr354, Thr364, Thr369, Ser384, Ser390, } \\
\text { Thr418, Ser423 (MAP kinase ERK2) }\end{array}$ & $\begin{array}{l}26762 \\
26786 \text { (Mylona et al. 2016) }\end{array}$ \\
\hline $\begin{array}{l}\text { Disordered cytosolic domain CD79a of the B-cell } \\
\text { receptor }\end{array}$ & $\begin{array}{l}\text { Tyr182, Tyr188, Tyr199, Tyr210 (Src family kinase } \\
\text { Fyn) }\end{array}$ & $\begin{array}{l}19644 \\
19648 \text { (Rosenlow et al. 2014) }\end{array}$ \\
\hline
\end{tabular}

structural effects of phosphorylation in IDPs if we do not take the sequence effect into consideration. Finally, as the titration of the phosphate may also change the sequence correction factors, we extracted these over the $\mathrm{pH}$ range from pH 4.0 to 8.0 (SI Table 1).

\section{Revisiting the CS analyses of phosphorylated IDPs}

Since the obtained data allows for a more direct comparison of the effect of phosphorylation on the IDP ensemble from CS analyses only, we revisited previous published CS data sets and identified a set of phosphorylated IDPs published in the BMRB (Table 4). The following proteins were revisited: (i) the intrinsically disordered distal tail of NHE1 phosphorylated at five serine residues and one threonine by the MAPK kinase ERK2 (Hendus-Altenburger et al. 2017; Hendus-Altenburger et al. 2016), (ii) the disordered KID domain of the transcription factor CREB phosphorylated at one serine by protein kinase A (PKA) (Radhakrishnan et al. 1998), (iii) the transcriptional regulator Ash1 phosphorylated at eight serine and two threonine residues by cyclin A/Cdk2 (Martin et al. 2016), (iv) the disordered cytosolic domain CD79a of the B-cell receptor phosphorylated at four tyrosine residues by the Src family kinase Fyn (Rosenlow et al. 2014), (v) the regulatory region of CFTR fully phosphorylated at eight serine residues by PKA (Baker et al. 2007) and (vi) the transcriptional activation domain of the transcription factor Elk-1 phosphorylated at five threonine and three serine residues by ERK2 (Mylona et al. 2016). Besides NHE1, which had been previously analyzed using intrinsic reference coil values, the five additional proteins were chosen as they are phosphorylated by different kinases and thus have different substrate motifs surrounding the phosphorylation sites, as well as represent several examples of pSer, pThr and pTyr. Furthermore, we chose proteins with assignments around $\mathrm{pH} 7.0$, which is close to the 

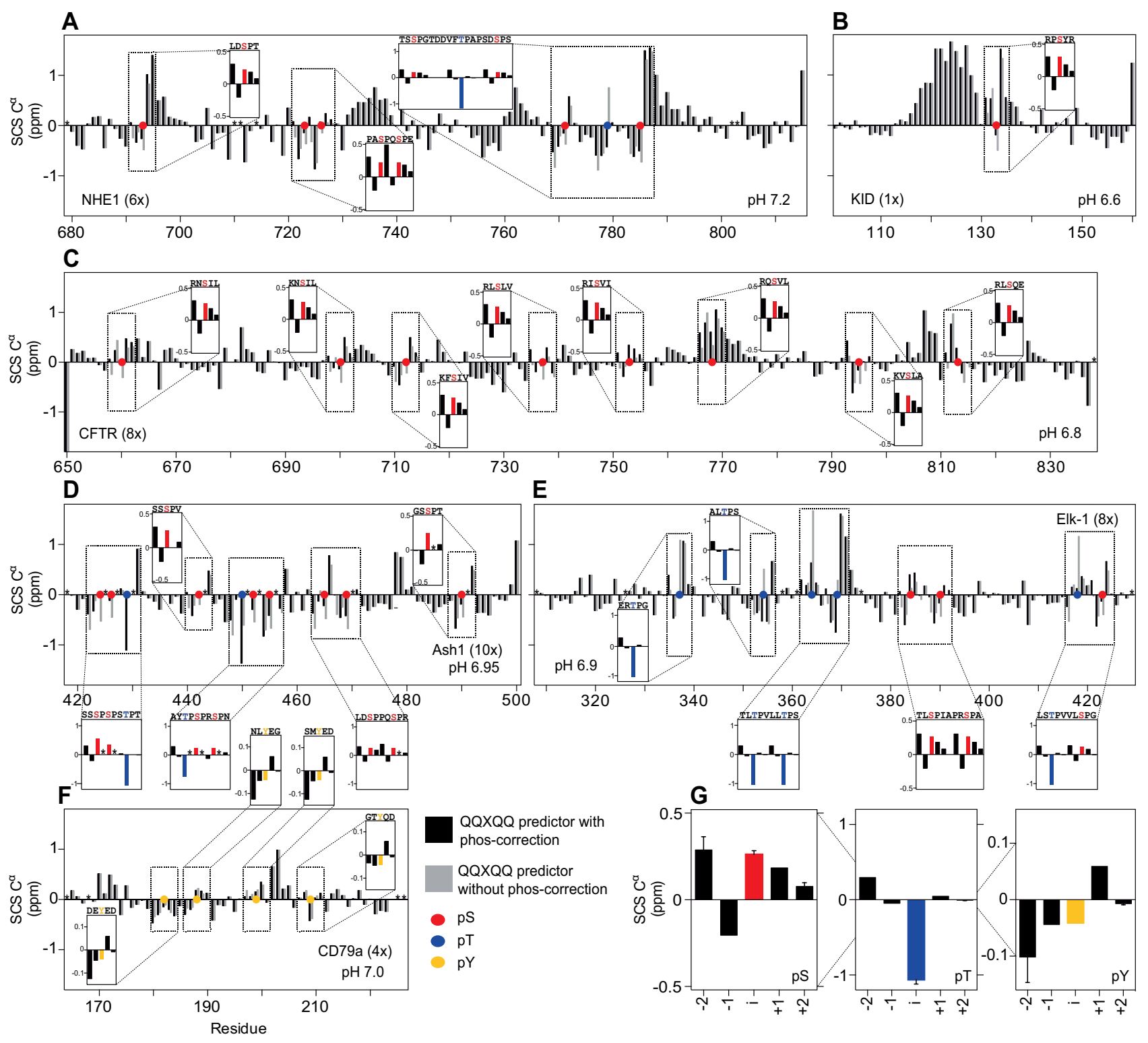

Fig. 3 Difference in secondary chemical shift prediction with and without the reference chemical shifts and correction factors for phosphorylated residues. Secondary $\mathrm{C}^{\alpha}$ chemical shifts $\left(\mathrm{SCS} \mathrm{C}^{\alpha}\right)$ from the predictor lacking the reference chemical shifts and correction factors for phosphorylated residues (grey) and with these included in the updated predictor (black) of the following phosphorylated proteins a NHE1, b KID domain, $\mathbf{c}$ R-region of CFTR, d Ash1, e Elk1, transac-

physiological range and commonly used for IDP studies. In total, this provided us with the possibility of examining the effects from four different kinases and phosphorylations of 25 serine-, eight threonine-, and four tyrosine sites. This allowed for extraction of some general observations.

For each phosphorylated protein, we calculated the random coil CS of the $\mathrm{C}^{\alpha} \mathrm{s}$ with and without the new corrections for phosphorylations and plotted these side by side on a per residues basis (Fig. 3a-e). For the residues surrounding tivation domain and $\mathbf{f}$ CD79a. Subtraction of the SCS of the previous predictor from the SCS of the updated predictor $\left(\mathrm{SCS}_{\text {new }}-\mathrm{SCS}_{\text {old }}\right)$ are shown for each phosphorylated region in the highlighted boxes. $\mathbf{g}$ Difference for pSer, pThr and pTyr, averaged over all analyzed sites. Colored bars, dots and letters indicate the phosphorylated residues. Black stars indicate unassigned residues

the phosphorylation sites we calculated the difference $\left(\delta_{\text {RCnon-phos }}-\delta_{\text {RCphos }}\right.$, see inserts in Fig. 3a-e) and averaged these for each of the three residue types (Fig. 3g). Generally, we observed that the differences in random coil shifts were independent on the neighboring residues or the kinase used, as expected. For a phosphorylated serine, the use of a unphosphorylated random coil set underestimates the SCS of the $\mathrm{C}^{\alpha}$ of the i-2 position with $0.3 \mathrm{ppm}$, overestimates it with 0.15 ppm at the $\mathrm{i}-1$ position, and with $0.15 \mathrm{ppm}$ at the 

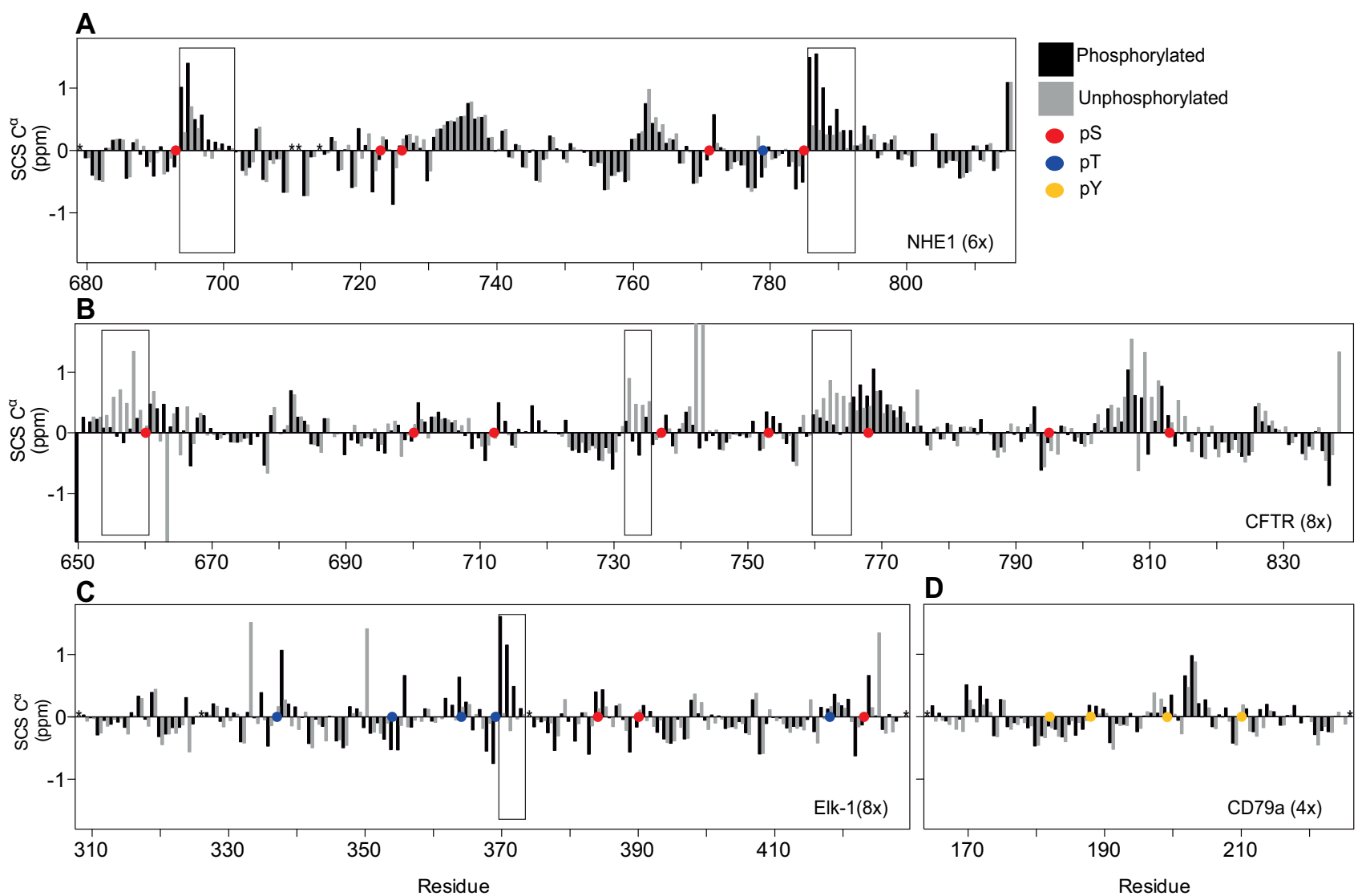

Fig. 4 Effect of phosphorylation on secondary structure in a selected set of IDPs. Secondary $C^{\alpha}$ chemical shifts $\left(\mathrm{SCS} \mathrm{C}^{\alpha}\right)$ for the unphosphorylated and phosphorylated states are compared for a the disordered distal tail of NHE1, b R-region of CFTR, c Elk-1, and d

pSer, with minor overestimations on the $i+1$ and $i+2$ positions. For the phosphorylated threonine residues, the effects are much stronger. Similar underestimations of $0.3 \mathrm{ppm}$ at the $\mathrm{i}-2$ position are seen, but with overestimations of as much as $1 \mathrm{ppm}$ at the pThr position (i). Smaller underestimations are seen on the $i+1$ and $i+2$ positions. Much smaller effects were again seen for the phosphorylated tyrosine, with highly similar effects independent of the sequence.

We then translated these effects into how stabilization and destabilization of transient structures by phosphorylations would potentially be masked or modulated by the absence of a proper random coil CS data set. For this, we examined the CSs of a set of phosphorylated proteins and compared the SCSs in the unphosphorylated state with those of the phosphorylated state using the implemented random coil sets (Fig. 4). For NHE1, the six times ERK2phosphorylated state had previously been analyzed using intrinsic random coil values, where the CSs of the phosphorylated state were assigned in urea (Hendus-Altenburger et al. 2017). It was evident that phosphorylations induced helicity at two out of six sites, which could be
CD79a. Boxes indicate regions with structural modulation. Colored dots indicate the phosphorylated residues (red/blue/yellow for pSer/ $\mathrm{pThr} / \mathrm{pTyr}$ respectively). Black stars indicate unassigned residues

linked to the presence of arginine residues positioned in $\mathrm{i}+5$ positions (Hendus-Altenburger et al. 2017). The SCSs derived using the predictor accounting for phosphorylation agree very well with those derived from the urea unfolded state, detecting helix stabilization by pSer693 and pSer785 with no effects induced by the other four phosphorylations. However, omitting phosphorylation correction, this effect was underestimated roughly fourfold (Fig. 4a). For CFTR it was previously suggested that there was a global decrease in helicity upon phosphorylation, with stabilization of the helix by pSer768, while pSer700, pSer737 and pSer813 all destabilized helices. Using the new predictor, three regions with a decrease in helicity can be observed, all located N-terminal to the phosphorylation sites, i.e. N-terminal to pSer660, pSer737 and pSer768. Also, a minor stabilization at pSer768 between $\mathrm{i}-2$ until $i+1$ is detected. However, no significant effect is seen for pS700 and more random changes are observed for pS813 (Fig. 4b). This highlights the importance of separating structural from chemical effects, as omitting this can lead to over/underestimation of structural modulation by 
phosphorylation. For Elk-1, most phosphorylations had no significant effect on the secondary structure except for pSer369, where induction of helicity was observed (Fig. 4c). No significant effect of tyrosine phosphorylation on the secondary structure was seen for CD79a (Fig. 4d).

Taken together, the use of the new predictor of random coil CS values for phosphorylated proteins allowed for more accurate detection of the transient secondary structures of phosphoproteins. The effects of phosphorylation could now be directly separated from the chemical effect and enabled quantification of the structure modulating effects of phosphorylation. Generally, a phosphorylation N-terminal to transient helicity stabilized the helical structure, and when the phosphorylation site was positioned C-terminal to transient structure, helicity was destabilized, in agreement with previous observations (Andrew et al. 2002). Further, the new predictor allows for $\mathrm{pH}$ corrected CS predictions, which is critical as phosphate titrates in the physiological $\mathrm{pH}$ range with considerable effects on the carbon CSs, eliminating spurious spikes in the secondary CSs. The large effect of phosphorylation on threonine CSs combined with its strong $\mathrm{pH}$ sensitivity, warrants extra care in interpreting structural effects from threonine phosphorylation in general.

Extraction of local structure from CSs has been possible for 50 years (Markley et al. 1967) and the random coil CS databases and peptide-derived libraries continue to improve both in accuracy and precision of the correction factors for sequence and sample conditions like temperature and $\mathrm{pH}$ (Kjaergaard et al. 2011; Kjaergaard and Poulsen 2011; Schwarzinger et al. 2001). With the inclusion of a full set of random coil shifts for phosphorylated side chains in proteins and their $\mathrm{pH}$ and temperature dependence covering the range of the $\mathrm{pKa}$ values of the phosphates, we can more reliably analyze and decompose the effects of phosphorylations on the structural ensemble.

Acknowledgements We thank Magnus Kjaergaard for fruitful discussions and Andreas Prestel for help with NMR recordings. This work was supported by Grants from the Danish Research Councils (to B.B.K./W.B.: 4181-00344), the Lundbeck Foundation (M.B.A.K./R.HA), and the Novo Nordisk Foundation SYNERGY Grant (B.B.K) and Challenge Grant, REPIN (B.B.K). The Villumfonden is thanked for generous support for NMR instruments.

Data availability The online predictor of random coil chemical shifts for unphosphorylated and phosphorylated sequences is available at www.bio.ku.dk/sbinlab/randomcoil.

Open Access This article is distributed under the terms of the Creative Commons Attribution 4.0 International License (http://creativeco mmons.org/licenses/by/4.0/), which permits unrestricted use, distribution, and reproduction in any medium, provided you give appropriate credit to the original author(s) and the source, provide a link to the Creative Commons license, and indicate if changes were made.

\section{References}

Andrew CD, Warwicker J, Jones GR, Doig AJ (2002) Effect of phosphorylation on alpha-helix stability as a function of position. Biochemistry 41:1897-1905

Bah A, Vernon RM, Siddiqui Z, Krzeminski M, Muhandiram R, Zhao C, Sonenberg N, Kay LE, Forman-Kay JD (2015) Folding of an intrinsically disordered protein by phosphorylation as a regulatory switch. Nature 519:106-109

Baker JM, Hudson RP, Kanelis V, Choy WY, Thibodeau PH, Thomas PJ, Forman-Kay JD (2007) CFTR regulatory region interacts with NBD1 predominantly via multiple transient helices. Nat Struct Mol Biol 14:738-745

Bienkiewicz EA, Lumb KJ (1999) Random-coil chemical shifts of phosphorylated amino acids. J Biomol NMR 15:203-206

Buckingham AD (1960) Chemical shifts in the nuclear magnetic resonance spectra of molecules containing polar groups. Can J Chem 38:300-307

Bui JM, Gsponer J (2014) Phosphorylation of an intrinsically disordered segment in Ets1 shifts conformational sampling toward binding-competent substates. Structure 22:1196-1203

Camilloni C, De Simone A, Vranken WF, Vendruscolo M (2012) Determination of secondary structure populations in disordered states of proteins using nuclear magnetic resonance chemical shifts. Biochemistry 51:2224-2231

Cierpicki T, Otlewski J (2001) Amide proton temperature coefficients as hydrogen bond indicators in proteins. J Biomol NMR 21:249-261

Conibear AC, Rosengren KJ, Becker CFW, Kaehlig H (2019) Random coil shifts of posttranslationally modified amino acids. J Biomol NMR. https://doi.org/10.1007/s10858-019-00270-4

Delaglio F, Grzesiek S, Vuister GW, Zhu G, Pfeifer J, Bax A (1995) NMRPipe: a multidimensional spectral processing system based on UNIX pipes. J Biomol NMR 6:277-293

Du JT, Li YM, Wei W, Wu GS, Zhao YF, Kanazawa K, Nemoto T, Nakanishi H (2005) Low-barrier hydrogen bond between phosphate and the amide group in phosphopeptide. J Am Chem Soc 127:16350-16351

Dyson HJ, Wright PE (1991) Defining solution conformations of small linear peptides. Annu Rev Biophys Biophys Chem 20:519-538

Elam WA, Schrank TP, Campagnolo AJ, Hilser VJ (2013) Temperature and urea have opposing impacts on polyproline II conformational bias. Biochemistry 52:949-958

Espinoza-Fonseca LM, Kast D, Thomas DD (2008) Thermodynamic and structural basis of phosphorylation-induced disorder-to-order transition in the regulatory light chain of smooth muscle myosin. J Am Chem Soc 130:12208-12209

Fedyukina DV, Rajagopalan S, Sekhar A, Fulmer EC, Eun YJ, Cavagnero $S$ (2010) Contribution of long-range interactions to the secondary structure of an unfolded globin. Biophys J 99:L37-L39

Forman-Kay Julie D, Mittag T (2013) From sequence and forces to structure, function, and evolution of intrinsically disordered proteins. Structure 21:1492-1499

Haxholm GW, Nikolajsen LF, Olsen JG, Fredsted J, Larsen FH, Goffin V, Pedersen SF, Brooks AJ, Waters MJ, Kragelund BB (2015) Intrinsically disordered cytoplasmic domains of two cytokine receptors mediate conserved interactions with membranes. Biochem J 468:495-506

Hendus-Altenburger R, Pedraz-Cuesta E, Olesen CW, Papaleo E, Schnell JA, Hopper JT, Robinson CV, Pedersen SF, Kragelund BB (2016) The human $\mathrm{Na}(+) / \mathrm{H}(+)$ exchanger 1 is a membrane scaffold protein for extracellular signal-regulated kinase 2. BMC Biol 14:31

Hendus-Altenburger R, Lambrughi M, Terkelsen T, Pedersen SF, Papaleo E, Lindorff-Larsen K, Kragelund BB (2017) A 
phosphorylation-motif for tuneable helix stabilisation in intrinsically disordered proteins-lessons from the sodium proton exchanger 1 (NHE1). Cell Signal 37:40-51

Hoffmann R, Reichert I, Wachs WO, Zeppezauer M, Kalbitzer HR (1994) 1H and 31P NMR spectroscopy of phosphorylated model peptides. Int J Pept Protein Res 44:193-198

Iakoucheva LM, Radivojac P, Brown CJ, O'Connor TR, Sikes JG, Obradovic Z, Dunker AK (2004) The importance of intrinsic disorder for protein phosphorylation. Nucleic Acids Res 32:1037-1049

Kang YJ, Zuo LM, Luo SZ (2010) Hydrogen-bonding interactions induced by phosphorylation influence the local conformation of phosphopeptides. Int J Pept Res Ther 16:87-93

Kim SY, Jung Y, Hwang GS, Han H, Cho M (2011) Phosphorylation alters backbone conformational preferences of serine and threonine peptides. Proteins 79:3155-3165

Kjaergaard M, Poulsen FM (2011) Sequence correction of random coil chemical shifts: correlation between neighbor correction factors and changes in the Ramachandran distribution. J Biomol NMR 50:157-165

Kjaergaard M, Norholm AB, Hendus-Altenburger R, Pedersen SF, Poulsen FM, Kragelund BB (2010) Temperature-dependent structural changes in intrinsically disordered proteins: formation of alpha-helices or loss of polyproline II? Protein Sci 19:1555-1564

Kjaergaard M, Brander S, Poulsen FM (2011) Random coil chemical shift for intrinsically disordered proteins: effects of temperature and $\mathrm{pH}$. J Biomol NMR 49:139-149

Kukic P, Farrell D, McIntosh LP, Garcia-Moreno EB, Jensen KS, Toleikis Z, Teilum K, Nielsen JE (2013) Protein dielectric constants determined from NMR chemical shift perturbations. J Am Chem Soc 135:16968-16976

Lee KK, Kim E, Joo C, Song J, Han H, Cho M (2008) Site-selective intramolecular hydrogen-bonding interactions in phosphorylated serine and threonine dipeptides. J Phys Chem B 112:16782-16787

Mandell DJ, Chorny I, Groban ES, Wong SE, Levine E, Rapp CS, Jacobson MP (2007) Strengths of hydrogen bonds involving phosphorylated amino acid side chains. J Am Chem Soc 129:820-827

Markley JL, Meadows DH, Jardetzky O (1967) Nuclear magnetic resonance studies of helix-coil transitions in polyamino acids. J Mol Biol 27:25-40

Marsh JA, Singh VK, Jia Z, Forman-Kay JD (2006) Sensitivity of secondary structure propensities to sequence differences between alpha- and gamma-synuclein: implications for fibrillation. Protein Sci 15:2795-2804

Martin EW, Holehouse AS, Grace CR, Hughes A, Pappu RV, Mittag $\mathrm{T}$ (2016) Sequence determinants of the conformational properties of an intrinsically disordered protein prior to and upon multisite phosphorylation. J Am Chem Soc 138:15323-15335

Miranda FF, Thorolfsson M, Teigen K, Sanchez-Ruiz JM, Martinez A (2004) Structural and stability effects of phosphorylation: localized structural changes in phenylalanine hydroxylase. Protein Sci 13:1219-1226

Modig K, Jurgensen VW, Lindorff-Larsen K, Fieber W, Bohr HG, Poulsen FM (2007) Detection of initiation sites in protein folding of the four helix bundle ACBP by chemical shift analysis. FEBS Lett 581:4965-4971

Mylona A, Theillet FX, Foster C, Cheng TM, Miralles F, Bates PA, Selenko P, Treisman R (2016) Opposing effects of Elk-1 multisite phosphorylation shape its response to ERK activation. Science 354:233-237

Nielsen JT, Mulder FAA (2018) POTENCI: prediction of temperature, neighbor and $\mathrm{pH}$-corrected chemical shifts for intrinsically disordered proteins. J Biomol NMR 70(3):141-165

Piotto M, Saudek V, Sklenář V (1992) Gradient-tailored excitation for single-quantum NMR spectroscopy of aqueous solutions. J Biomol NMR 2:661-665
Radhakrishnan I, Perez-Alvarado GC, Dyson HJ, Wright PE (1998) Conformational preferences in the Ser133-phosphorylated and non-phosphorylated forms of the kinase inducible transactivation domain of CREB. FEBS Lett 430:317-322

Ramelot TA, Nicholson LK (2001) Phosphorylation-induced structural changes in the amyloid precursor protein cytoplasmic tail detected by NMR. J Mol Biol 307:871-884

Rani L, Mallajosyula SS (2017) Phosphorylation versus O-GlcNAcylation: computational insights into the differential influences of the two competitive post-translational modifications. J Phys Chem B 121:10618-10638

Rosenlow J, Isaksson L, Mayzel M, Lengqvist J, Orekhov VY (2014) Tyrosine phosphorylation within the intrinsically disordered cytosolic domains of the B-cell receptor: an NMR-based structural analysis. PLoS ONE 9:e96199

Schwarzinger S, Kroon GJ, Foss TR, Chung J, Wright PE, Dyson HJ (2001) Sequence-dependent correction of random coil NMR chemical shifts. J Am Chem Soc 123:2970-2978

Shen Y, Roche J, Grishaev A, Bax A (2018) Prediction of nearest neighbor effects on backbone torsion angles and NMR scalar coupling constants in disordered proteins. Protein Sci 27:146-158

Sibille N, Huvent I, Fauquant C, Verdegem D, Amniai L, Leroy A, Wieruszeski JM, Lippens G, Landrieu I (2012) Structural characterization by nuclear magnetic resonance of the impact of phosphorylation in the proline-rich region of the disordered Tau protein. Proteins 80:454-462

Tamiola K, Acar B, Mulder FA (2010) Sequence-specific random coil chemical shifts of intrinsically disordered proteins. J Am Chem Soc 132:18000-18003

Tamiola K, Scheek RM, van der Meulen P, Mulder FAA (2018) pepKalc: scalable and comprehensive calculation of electrostatic interactions in random coil polypeptides. Bioinformatics 34:2053-2060

Theillet FX, Smet-Nocca C, Liokatis S, Thongwichian R, Kosten J, Yoon MK, Kriwacki RW, Landrieu I, Lippens G, Selenko P (2012) Cell signaling, post-translational protein modifications and NMR spectroscopy. J Biomol NMR 54:217-236

Tholey A, Lindemann A, Kinzel V, Reed J (1999) Direct effects of phosphorylation on the preferred backbone conformation of peptides: a nuclear magnetic resonance study. Biophys J 76:76-87

Tomlinson JH, Green VL, Baker PJ, Williamson MP (2010) Structural origins of $\mathrm{pH}$-dependent chemical shifts in the $\mathrm{B} 1$ domain of protein G. Proteins 78:3000-3016

Tyanova S, Cox J, Olsen J, Mann M, Frishman D (2013) Phosphorylation variation during the cell cycle scales with structural propensities of proteins. PLoS Comput Biol 9:e1002842

Vranken WF, Boucher W, Stevens TJ, Fogh RH, Pajon A, Llinas M, Ulrich EL, Markley JL, Ionides J, Laue ED (2005) The CCPN data model for NMR spectroscopy: development of a software pipeline. Proteins 59:687-696

Ward JJ, Sodhi JS, McGuffin LJ, Buxton BF, Jones DT (2004) Prediction and functional analysis of native disorder in proteins from the three kingdoms of life. J Mol Biol 337:635-645

Whittington SJ, Chellgren BW, Hermann VM, Creamer TP (2005) Urea promotes polyproline II helix formation: implications for protein denatured states. Biochemistry 44:6269-6275

Wishart DS (2011) Interpreting protein chemical shift data. Prog Nucl Magn Reson Spectrosc 58:62-87

Wishart DS, Bigam CG, Holm A, Hodges RS, Sykes BD (1995a) 1H, $13 \mathrm{C}$ and $15 \mathrm{~N}$ random coil NMR chemical shifts of the common amino acids. I. Investigations of nearest-neighbor effects. J Biomol NMR 5:67-81

Wishart DS, Bigam CG, Yao J, Abildgaard F, Dyson HJ, Oldfield E, Markley JL, Sykes BD (1995b) 1H, 13C and $15 \mathrm{~N}$ chemical shift referencing in biomolecular NMR. J Biomol NMR 6:135-140 
Wright PE, Dyson HJ (2015) Intrinsically disordered proteins in cellular signalling and regulation. Nat Rev Mol Cell Biol 16:18-29

Xue B, Dunker AK, Uversky VN (2012) Orderly order in protein intrinsic disorder distribution: disorder in 3500 proteomes from viruses and the three domains of life. J Biomol Struct Dyn 30:137-149
Publisher's Note Springer Nature remains neutral with regard to jurisdictional claims in published maps and institutional affiliations. 